\title{
Radiocarbon dated malacological records of two Late Pleistocene loess-paleosol sequences from SW-Hungary: Paleoecological inferences
}

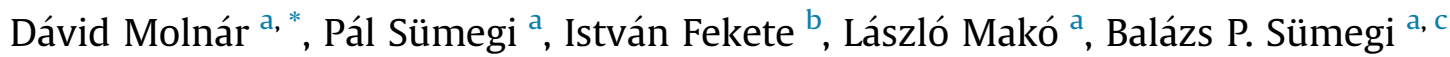 \\ a Department of Geology and Paleontology, University of Szeged, H-6722, Szeged, Egyetem u. 2-6, Hungary \\ b Department of Physical Geography and Geoinformatics, University of Szeged, H-6722, Szeged, Egyetem u. 2-6, Hungary \\ ${ }^{\mathrm{c}}$ Isotope Climatology and Environmental Research Centre, Institute for Nuclear Research, Hungarian Academy of Sciences, Debrecen, Hungary
}

\section{A R T I C L E I N F O}

\section{Article history:}

Received 29 May 2017

Received in revised form

13 December 2017

Accepted 21 January 2018

Available online 1 February 2018

\section{Keywords:}

Loess-paleosol sequence

Malacology

Late Pleistocene

Hungary

Villánykövesd

Máza

\begin{abstract}
A B S T R A C T
The two loess-paleosol sequences of Villánykövesd and Máza preserved specific paleoecological information of the Late Pleistocene environmental conditions in SW-Hungary. For malacological examinations, sampling of $12 \mathrm{~cm}$ intervals were used; homogenous amounts of sediment (ca. $5 \mathrm{~kg}$ ) were collected. During the malacological examinations, more than 27,000 specimens were identified. Interpreting their environmental and climatic demands the paleoclimate and paleoenvironment of the last 80,000 years could be reconstructed. The results of the malacological investigations of Villánykövesd sequence indicated 5 malacological zones (MZs) by the snail species' dominant occurrence. All of the 5 MZs indicate mild climatic conditions with only one cooling phase. The mild climatic conditions were reconstructed by the high dominance of thermophilous species, especially Pupilla triplicata. This warmth loving, xerophilous and open vegetation preferring species is present in the entire sequence, which indicates a refuge area of $P$. triplicata around Villánykövesd. At the Máza sequence, 9 MZs could be allocated with mainly dominance of cold resistant species, indicating cooler climatic conditions than at Villánykövesd. The reason of the high ratio of cold resistant species and the high number of MZs could be the geographic exposition of the Máza sequence. The Máza sequence is located in a bench between higher and lower reliefs on the northern pediment area of Mecsek Mountains. This indicates the presence of a fluctuation zone for the snail species in the area of Máza sequence. The Late Pleistocene sequences possess different climatic and environmental conditions during same timeframe, therefore we highlight that the previously reconstructed mosaic-like environmental patters in the Carpathian Basin are real properties in the region.
\end{abstract}

() 2018 Elsevier Ltd and INQUA. All rights reserved.

\section{Introduction}

Loessy sediments are widespread in the Carpathian Basin, covering 10-15\% of its area (Sümegi, 2001, 2005, 2007). For paleoecological reconstructions, these sediments are the most eligible from the Quaternary because these can provide various data from a relatively short timeframe. This is why loessy sediments of the Carpathian Basin are well investigated. The main investigation areas from Hungary are the Bácska loess plateau (Sümegi, 2005; Hupuczi and Sümegi, 2010; Sümegi et al., 2014), the high bank of the Danube River (Horváth, 1954; Hum, 1998; Hum and Sümegi, 2001; Újvári

\footnotetext{
* Corresponding author.

E-mail address: molnard@geo.u-szeged.hu (D. Molnár).
}

et al., 2010, 2014, 2016; Bösken et al., 2017, in press), even the high bank of the Danube River in Croatia (Galović et al., 2009; Molnár and Sümegi, 2016; Molnár et al., 2010,2011, 2014) and the Vojvodina loess plateau in Serbia (Marković et al., 2004, 2005, 2006, 2007, 2008). This paper represents mollusc-based paleoecological reconstructions from a less investigated area of Hungary, two loess-paleosol sequences of Villánykövesd and Máza from the SE part of the Transdanubia region (Fig. 1). Local and global climatic and paleoenvironmental effects are investigated in both sequences to obtain detailed results from the Late Pleistocene period.

\section{Material and methods}

It can be said that malacological examinations may produce the 


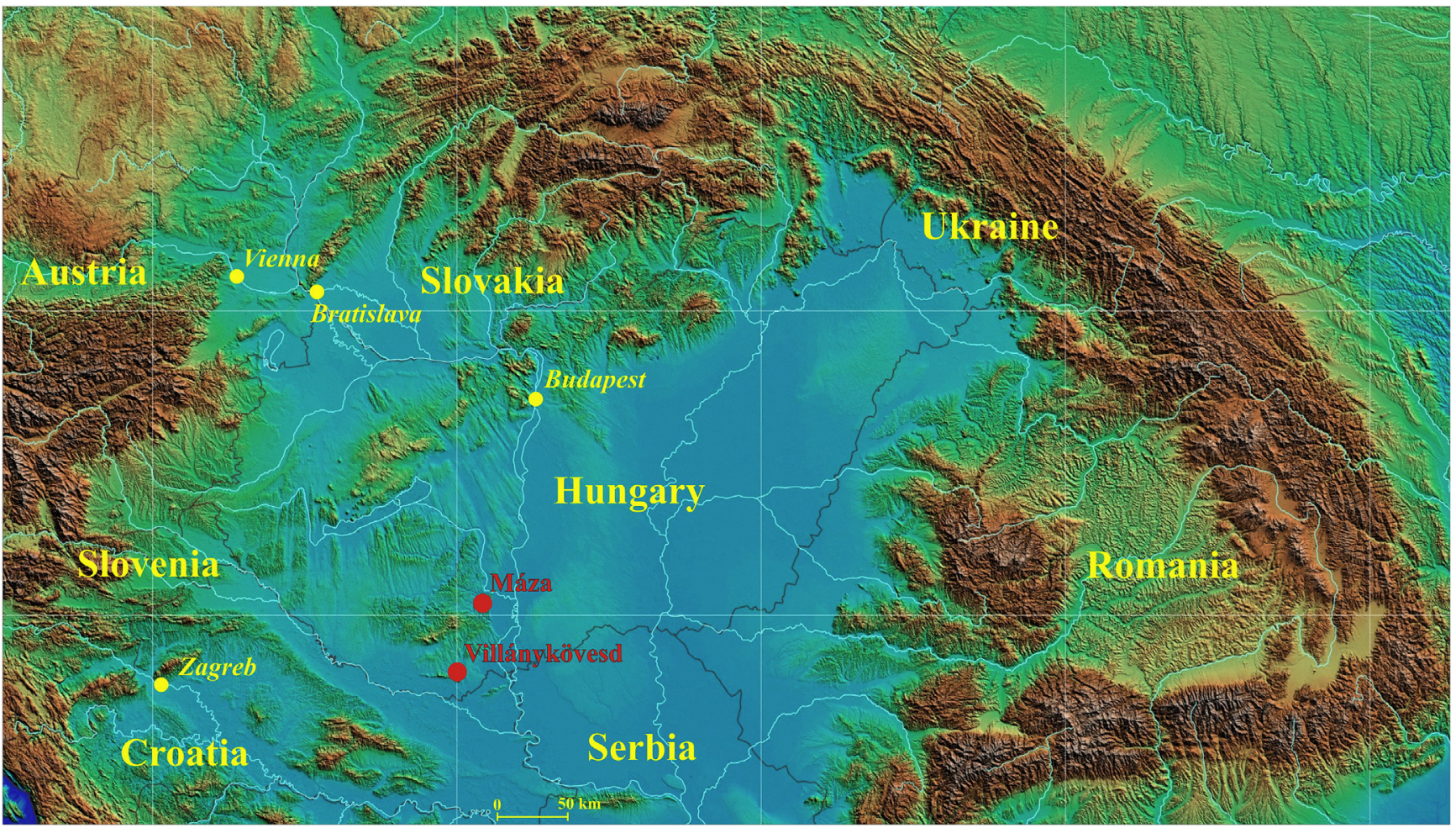

Fig. 1. Location of the investigated loess-paleosol profiles in Hungary and in the Carpathian Basin.

most comprehensive data about the climatic and environmental changes of a given area as reconstructed form loess. Certainly, high resolution $(2-4 \mathrm{~cm})$ examinations produce more accurate results from a shorter timeframe (Sümegi, 1996, 2003, 2004, 2007; Hupuczi and Sümegi, 2010; Persaits and Sümegi, 2011; Bösken et al., 2017, in press). The employed sampling resolution for the examined sequences was $12 \mathrm{~cm}$, because this resolution is used for the non-examined sequences.

The malacological examination contains 3 steps: sampling, wetscreening and shell identifying. After the sequence is cleaned, the sampling starts, ca. $5 \mathrm{~kg}$ (Sümegi, 1996) of sediment is collected from every $12 \mathrm{~cm}$ of the wall. Then every sample is wet-sieved through a $0.8 \mathrm{~mm}$ sieve. Before this procedure, the dry sediment is prepared with $10 \%$ concentrated $\mathrm{H}_{2} \mathrm{O}_{2}$ to clear the surface of the snail shells (Krolopp, 1983; Hum, 1998; Sümegi, 2001). Thereafter, the shells are assorted for identification. For this step, various identification books (Boycott, 1934; Soós L., 1943; Ant, 1963; Ložek, 1964; Kerney et al., 1983; Sysoev and Schileyko, 2009; WelterSchultes, 2012) were used. Identification, and even the knowledge of each species' climatic and environmental demands, can aid creating paleoecological reconstruction datasets with rather simple mathematical calculations (Krolopp, 1983; Sümegi, 1989; Krolopp and Sümegi, 1992, 1995; Sümegi and Krolopp, 1995), such as the species' abundance and dominance relations per sample. By using these datasets, the snail species can be clustered into paleoecological groups such as climatic, humidity and vegetation cover demands (Sümegi and Krolopp, 1995; Sümegi, 1996, 2001). All three factors depend upon each other, and even the changes in other (less important) conditions.

Absolute ages are vital to place the examined sequences in geologic time (e.g. Sümegi, 2005). Therefore, radiocarbon dating was used to fulfil this requirement by the help of the DirectAMS Lab, Seattle, USA. Calibrating the raw age was done using the Calib 7.0.4 software by using intcal13.14c calibration curve with two sigma ranges (Stuiver and Reimer, 1993). For the on-site lithologic description the Munsell Color Chart (Munsell, 1905) was employed. For making the figures, the Psimpoll software suite (Bennett, 1992) was used.

\section{Geographical setting and lithology}

Both loess-paleosol sequences are positioned west of the Danube River (right bank) in the south-eastern part of Transdanubia region in Hungary (Fig. 1). The loess-paleosol sequence of Villánykövesd is located between the villages of Villány and Villánykövesd, at the northernmost part of Villánykövesd brickyard $\left(45^{\circ} 52^{\prime} 52.77^{\prime \prime} \mathrm{N}, 18^{\circ} 26^{\prime} 23.40^{\prime \prime} \mathrm{E}\right)$. The elevation of the sequence is $127 \mathrm{~m}$ a.s.l., the height of the sequence was $805 \mathrm{~cm}$. The Máza sequence is situated between the villages of Máza and Nagymányok, at the northern part of the mineyard of an old brick factory $\left(46^{\circ} 17^{\prime} 09.58^{\prime \prime} \mathrm{N}, 18^{\circ} 24^{\prime} 21.15^{\prime \prime} \mathrm{E}\right)$ at an altitude of $164 \mathrm{~m}$ a.s.l., the profile height is $864 \mathrm{~cm}$.

For lithologic description the sediment layers were named using the Chinese loess-paleosol sequences' abbreviation terminology ("L" as loess and "S" as soil) (An et al., 1990; Ding et al., 2005; Gibbard and Cohen, 2008; Marković et al., 2008, 2015), further defined with the first letters of the sites: "V" for Villánykövesd, and “M” for Máza (Fig. 2).

\section{Results}

During the malacological examinations more than 27,000 snail shells were identified and clustered into three paleoecological groups by climatic- (thermophilous, mesophilous, cold-resistant and cryophilous), humidity- (xerophilous, mesophilous, subhygrophilous and hygrophilous) and vegetation cover demand (forest, ecotone and grassland dweller; Sümegi and Krolopp, 1995; Sümegi, 1996, 2001). By using these parameters, both sequences 


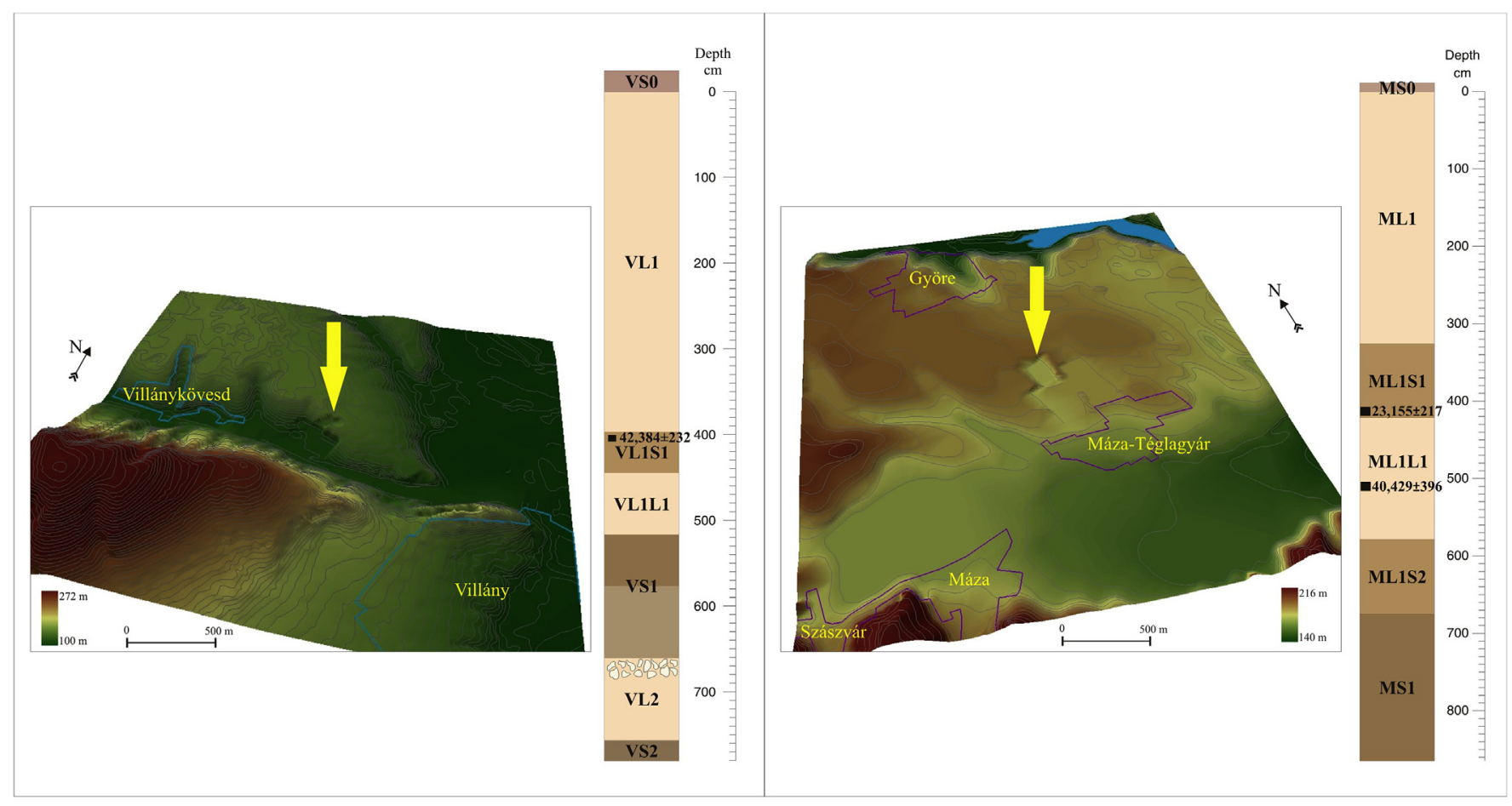

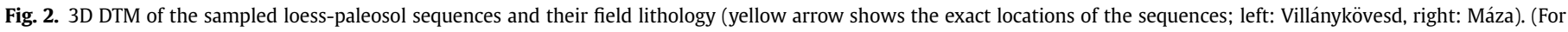
interpretation of the references to colour in this figure legend, the reader is referred to the Web version of this article.)

were divided into malacological zones (MZs), characterizing the climatic and environmental conditions in several depth/time frames.

\subsection{Villánykövesd}

The 65 samples of the Villánykövesd loess-paleosol sequence contained 11,657 identifiable snail shells of 26 terrestrial taxa. The average abundance distribution per sample was 179 , but it was not uniformly distributed (Fig. 3). Observing the dominance relations of the species, it is clear that the dominance values of 2 snail species (the warmth loving and xerophilous Pupilla triplicata and the mesophilous Vallonia costata) are prevalent. A similar increased dominance of these two species are noticeable at the Petrovaradin loess-paleosol sequence, in Serbia (Marković et al., 2005). At Villánykövesd, 5 malacological zones (MZs) could be identified (Figs. 3 and 4).

MZ-1 spans the lowermost part of the sequence $(780-680 \mathrm{~cm})$. At this zone, the dominance of thermophilous and open vegetation preferring species (P. triplicata, Helicopsis striata, Chondrula tridens, Granaria frumentum) is clear. Besides these, $V$. costata also appeared with rather high dominance values. Summarizing, this MZ indicates steppe vegetation with smaller forested areas supported by the presence of forest-dweller species, such as Vitrea subrimata and Limax sp.

MZ-2 corresponds to the VS1 paleosol layer $(680-515 \mathrm{~cm})$, with continuous domination of $P$. triplicata and $H$. striata, and the disappearance of $V$. costata. In addition, mesophilous and moisture preferring species were present (Vallonia pulchella, Nesovitrea hammonis). This indicates increased humidity, possibly owing to more extended forest areas or the appearance of long-grass steppe areas.

MZ-3 spans from 515 to $385 \mathrm{~cm}$, framing the VL1S1 and VL1L2 layers. It can be divided into 3 sub-zones according to the dominance changes of $V$. costata and $V$. pulchella. In the middle part of the zone most of warmth-loving species disappear, and clear dominance of $V$. pulchella and Limax species arise (Fig. 3). This means lower temperatures, higher humidity and probably a forestation period at this division of MZ-3. This level may correspond to GS 13 interstadial, around 46,000-48,000 years ago (Björck et al., 1998).

At the uppermost part of the zone, a radiocarbon age of $42,384 \pm 232$ cal BP years is established, which means that the VL1S1 paleosol layer may correlated with the GI 12 interstadial period (Björck et al., 1998; Tzedakis et al., 2006). Following the line, the VS1 paleosol layer, compared with Chinese results (Ding et al., 2005), could estimate to MIS 3 interstadial, between 47,000 and 52,000 years (Björck et al., 1998; Gibbard and Cohen, 2008).

In MZ-4 $(385-275 \mathrm{~cm})$ a slight cold period is indicated by warmth-loving species abundance reduction to around $40-50 \%$ (Fig. 4). In addition, several cold-resistant and cryophilous species (Trocholus hispidus and Vertigo pygmaea) occurred. Among the mesophilous species besides $V$. costata forest and ecotone species (Cochlicopa lubrica, Nesovitrea hammonis, Pucntum pygmaeum and Limax species) occurred. Although the number of sub- and hygrophilous and forest-dwelling species increased, their aggregated abundance is still lower than for the open vegetation dwelling species. During this weak cold period, the open environment prevailed, but the area of forests and even the ecotone area increased.

MZ-5 is located between $275 \mathrm{~cm}$ and the Holocene soil with clear dominance of warmth-loving species (besides $H$. striata and $C$. tridens the $P$. triplicata is outstanding). The mesophilous species $V$. costata appeared with significant abundance values, and even some forest species (Clausilia pumila, Vallonia enniensis, $N$. hammonis and Limax species) are present, proving that the steppe-forest mosaic environment persisted until the Holocene.

Two interesting dominance changes could be observed in MZ-5: a decrease of $P$. triplicata (from 75\% to 20\%) and increase of $V$. costata (from $15 \%$ to $60 \%$ ) in two levels around $250 \mathrm{~cm}$ (ca. 25-26,000 years ago) and $110 \mathrm{~cm}$ (ca. 15-16,000 years ago). The presence of T. hispidus and Aegopinella ressmanni species in these levels refer to 


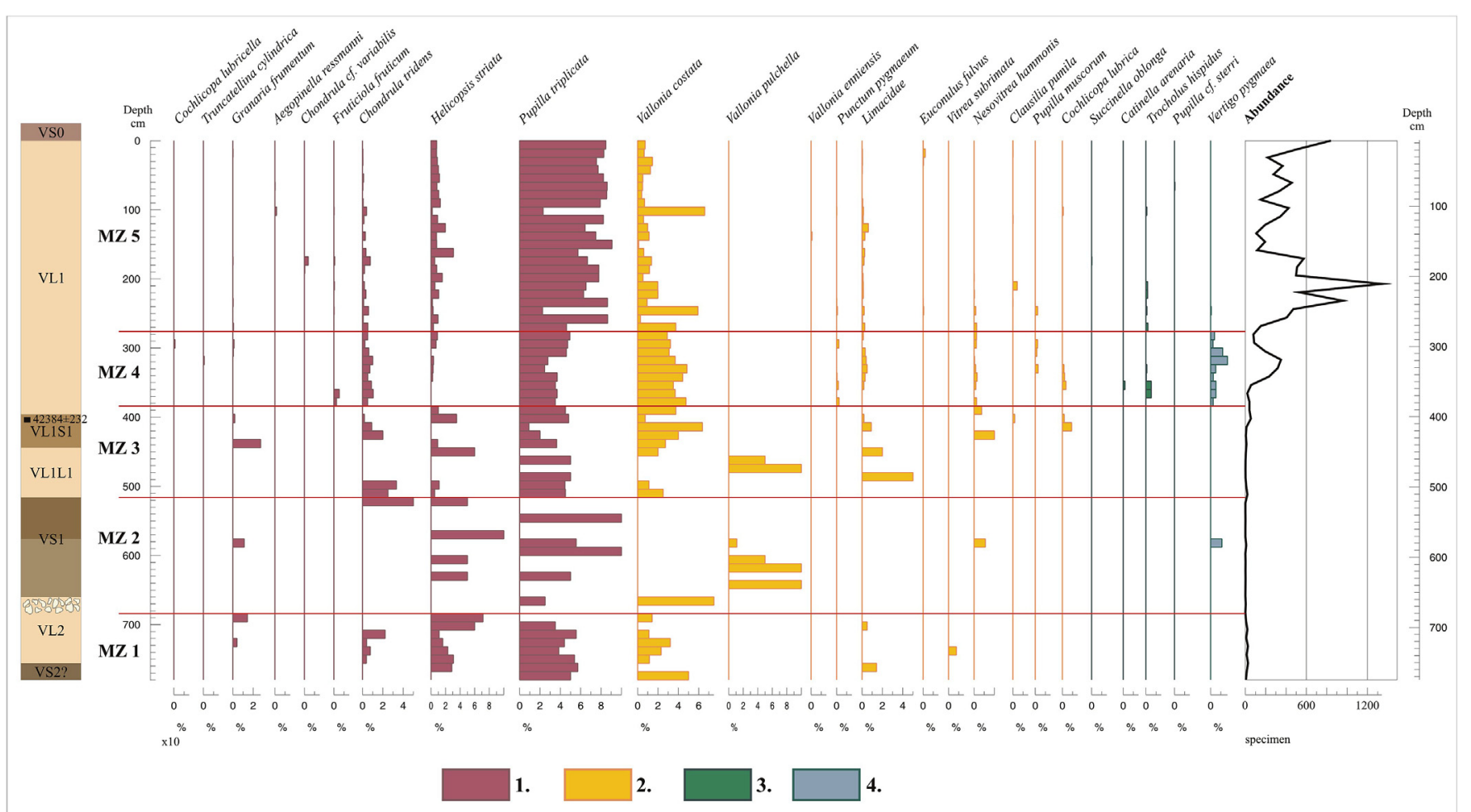

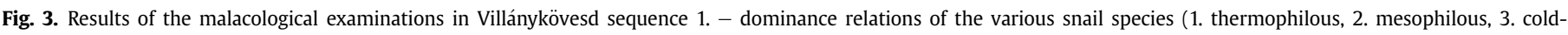
resistant, 4. cryophilous species).

extended forest area. According to the ages these levels may coincide with Heinrich events H1 (GS 2) and H2 (GS 3) (Bond et al., 1993; Björck et al., 1998; Hemming, 2004; Gibbard and Cohen, 2008).

\subsection{Máza}

15,570 shells were identified of 24 terrestrial snail species from the 72 samples of the Máza sequence. The average abundance per sample was 216, but it was not equal (Fig. 5). Exploring the dominance relations at the Máza loess-paleosol sequence, 9 malacological zones (MZs) could be separated (Figs. 5 and 6).

The lowermost MZ-1 is spanning from $864 \mathrm{~cm}$ to $840 \mathrm{~cm}$, covering the bottom part of the MS1 paleosol layer. The collective presence of the cold-resistant, hygrophilous, open vegetation preferring Succinella oblonga, the cold-resistant, sub-hygrophilous forest preferring Trocholus hispidus and the forest dwelling Limax species indicate a cool and partly forested paleoenvironment in this zone.

In the MZ-2 $(840-708 \mathrm{~cm})$, significant changes in the species composition occur, several warmth-loving, mainly open vegetation preferring (Helicopsis striata, Chondrula tridens, Granaria frumentum, Pupilla triplicata) and mesophilous (Pupilla muscorum, Vallonia costata) species occur in this zone. The open vegetation preferring and cold-resistant Quickella arenaria also occurred. Besides, the forest dwelling species (Limax sp., T. hispidus) disappear, indicating a warmer and less forested period in this zone. The warming should not have been strong because the dominance of cold-resistant species remained (Fig. 6).

MZ-3 extends between 708 and $492 \mathrm{~cm}$, containing the upper part of the MS1 paleosol, the ML1S2 paleosol and the ML1L1 loess layers. In this zone, high abundance values of $P$. muscorum, $P$. triplicata and $V$. costata occurred. Forest dwelling species (Limax species, T. hispidus and the mesoplilous Vallonia pulchella and
Nesovitrea hammonis) re-appear, besides other open vegetation preferring species (warmth-loving Cochlicopa lubricella and coldresistant Pupilla sterri) occur. Some cryophilous species are also present (forest dwelling Vallonia tenuilabris and ecotone Columella columella), indicating slightly colder temperatures in this MZ. In this period, the forested area could have extended, but the open environment remained dominant.

Around $500 \mathrm{~cm}$, a radiocarbon age of $40,429 \pm 396$ cal BP years was obtained, so MZ-3 can be parallel with the GI 11 interstadial period (Björck et al., 1998; Gibbard and Cohen, 2008). Moreover, the increased abundance of $C$. tridens and $P$. triplicata may refer to this period (GI 11).

From $492 \mathrm{~cm}$ to $420 \mathrm{~cm}, \mathrm{MZ}-4$ can be defined with significant changes in dominance relations. The cryophilous $C$. columella shows highest values in this zone indicating a tough and cold period. From the thermophilous species, only P. triplicata occurs; from the mesophilous only Limax species is present. Besides these changes, the cold-resistant S. oblonga and T. hispidus species appeared, indicating a cold period where the area of open environment increased, the forested areas shrunk, which may have been a refuge for some forest species during this cold period.

The uppermost part of MZ-4 is dated to $23,155 \pm 217$ cal BP years, which indicates that the MZ-4 cold period corresponds to the H2 Heinrich event (GS 3 stadial; Bond et al., 1993; Björck et al., 1998; Hemming, 2004; Gibbard and Cohen, 2008).

MZ-5 spans from 420 to $360 \mathrm{~cm}$, and the VL1S1 paleosol layer. All cryophilous species disappeared and the dominance values of warmth-loving species slightly increased (Fig. 6). Besides, $P$. triplicata and $C$. tridens re-appeared with some mesopilous (P. muscorum, V. costata, Euconulus fulvus) and cold-resistant (P. sterri) species. These changes in dominance values indicate a generally milder climatic setting during this zone, and the area of forests could increase during this period.

In MZ-6 (360-258 cm), warmth-loving species disappear, the 


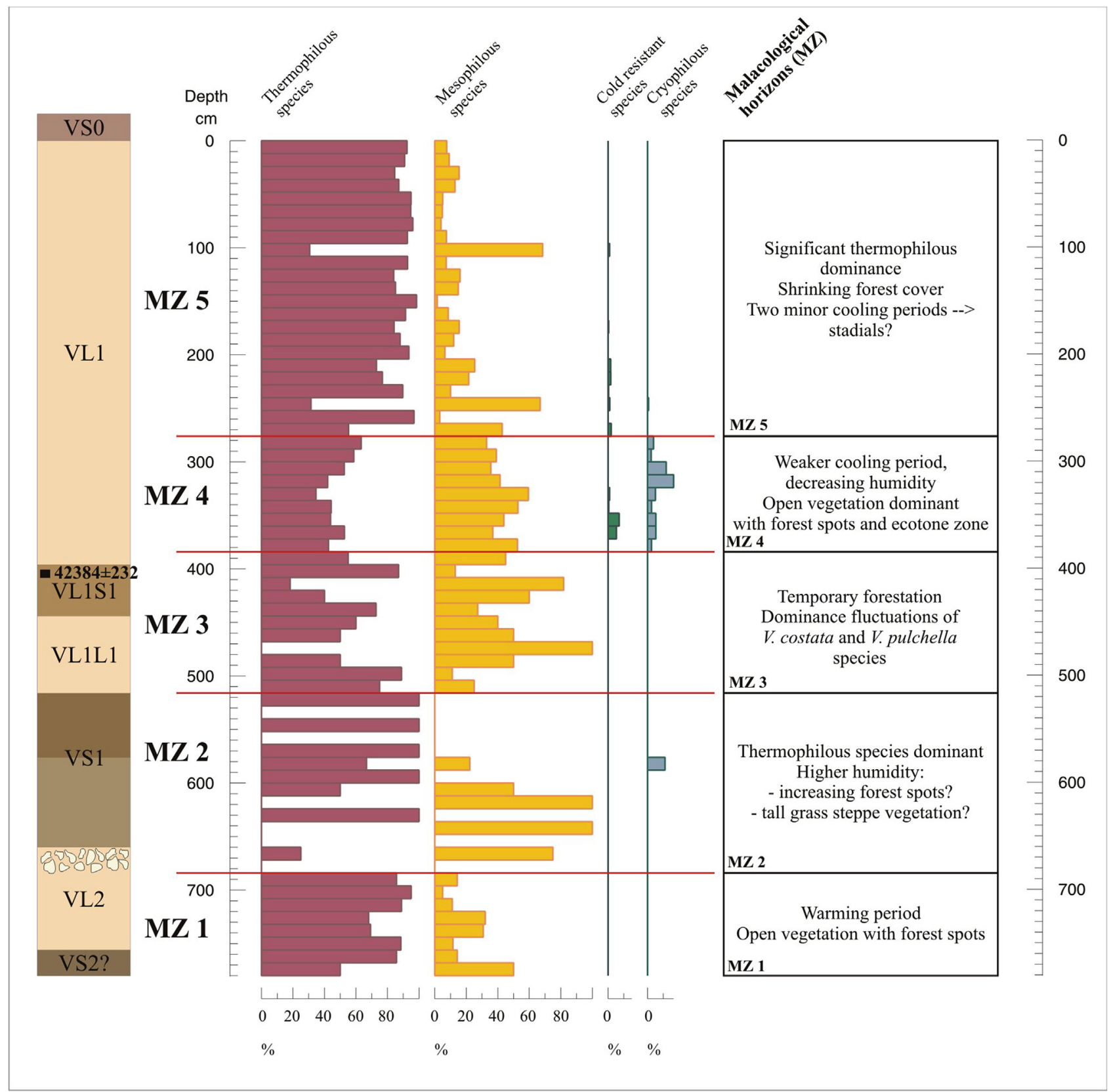

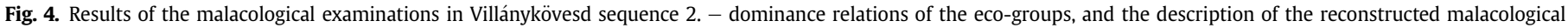
zones (MZs).

mesophilous ( $P$. muscorum) and cold-resistant ( $T$. hispidus, S. oblonga, $P$. sterri) dominate this zone. At the upper part of the zone, cryophilous species ( $V$. tenuilabris, $C$. columella) appear, but the mass dominance of these groups did not exceed the dominance of mesophilous species (Fig. 6). This zone could be a transition between the warmer MZ-5 and the cold MZ-7. The relatively high abundance values of $T$. hispidus indicate an extending forest area in this zone. At the border between MZ-6 and 7, several mesophilous ( $V$. costata, V. pulchella, Vitrea crystallina) and warmth-loving species (P. triplicata) appear, which indicates a short warming period, maybe related to the GI 3 stage (Björck et al., 1998; Gibbard and Cohen, 2008) at the borderline of the two MZs.

Cold-resistant species are present in MZ-7 $(258-180 \mathrm{~cm})$ with clear dominance of $T$. hispidus. Besides, the mesophilous $P$. muscorum, the cold-resistant S. oblonga and P. sterri occur with notable dominance values. The high abundance of $T$. hispidus refers to a cooling climate and emerging forested areas, maybe the most extended areas in the sequence, but the ratio of forest/open environment species was still low.

At MZ-8, between 180 and $12 \mathrm{~cm}$, a strong cooling period could be reconstructed by the dominance relations of snails (Figs. 5 and 6). The lack of warmth-loving species and the lower dominance of mesophilous species (only the P. muscourum represents higher values) combined with an increase of cold-resistant ( $T$. hispiudus, S. oblonga and P. sterri) and cryophilous species (V. tenuilabris, C. columella and Pupilla alpicola) indicates a strong cooling period in this MZ. The cold climate and the dominance relations of the species indicates mainly open vegetation with small forest spots, and indicates MIS 2 stage, maybe the Heinrich event H1 (Bond et al. 1993; Björck et al., 1998; Hemming, 2004; Gibbard and Cohen, 


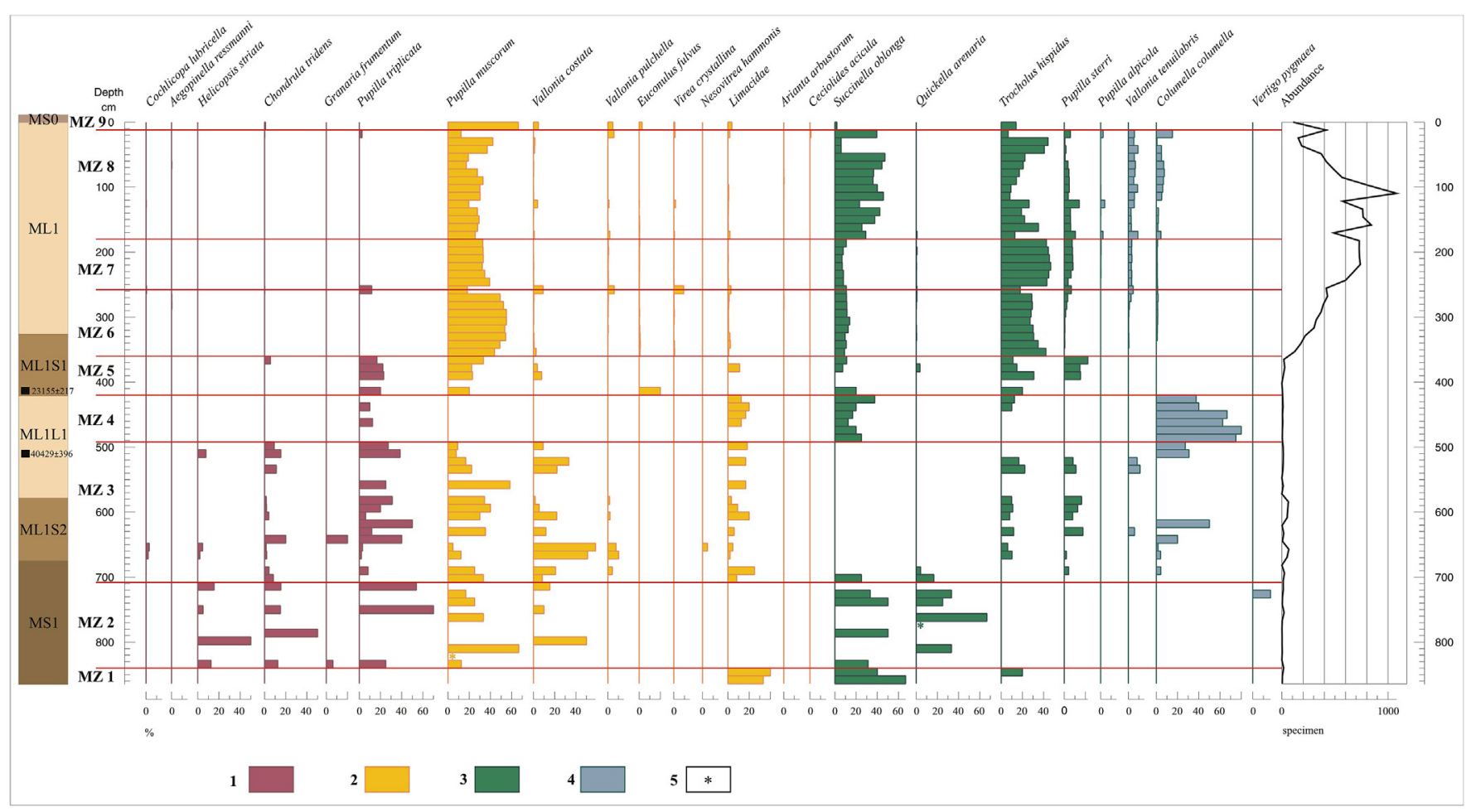

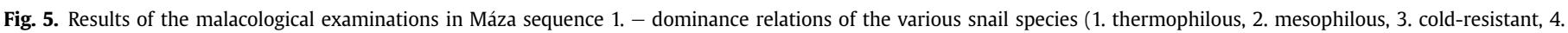
cryophilous species, 5 . fragment shells).

2008). The thickness of this zone may refer to intensive dust accumulation processes.

The uppermost and youngest MZ-9 contained only one sample but there are clear differences from the fauna of MZ-8. The cryophilous species disappear, from the cold-resistant only T. hispidus remained. Besides, mesophilous species appear (P. muscorum, $V$. pulchella, V. costata, E. fulvus, Limax sp.) with higher abundance values. These relations point to warming climatic conditions and the expansion of forested areas. This zone may represent the end of the Pleistocene or the beginning of the Holocene period.

\section{Discussion}

The results of malacological examinations of the Villánykövesd and Máza loess-paleosol sequences were correlated to each other, and were placed into the global timeline to compare the reconstructed paleoenvironmental conditions (Bronger, 2003). The setting of the sequences into the global timeline was made by their radiocarbon age data. Both sequences deposited during the Late Pleistocene period and three global stages (MIS) (Lisiecki and Raymo, 2005; Gibbard and Cohen, 2008) could be recognised (Fig. 7). Going back in time, the MIS 2 stage, or Last Glacial Maximum (LGM) could be revealed in both sequences' L1 layer (VL1 and ML1). By their setting and age, the paleosol layers in the Villánykövesd (VS1) and Máza (MS1) sequences could be placed in the MIS 3 interstadial, between ca. 47,000 and 51,000 cal BP years (Johnsen et al., 1995). The next warm stage is the MIS 5a interstadial (between ca. 75,000 and 83,000 cal BP years), which can only be investigated in the Villánykövesd sequence (VS2 layer; Fig. 7).

Besides the chronological correlation, it is essential to know each sequences' own environmental and climatic conditions. Correlating these, a more detailed chronological-paleoecological system could be established, which contains global and local data of climatic and environmental effects as derived from the investigated sequences. By the dominance relations of the snail species and the separated MZs, climatic and vegetation (forest coverage) zones, were reconstructed (Fig. 7). The reconstructed MIS stages remark different paleozones in each sequence, showing the local climatic impacts in the investigated area.

During the deposition of the Villánykövesd sequence, particularly warm climatic conditions prevailed (Fig. 7). The highest temperatures reconstructed in MZ-2 represent a paleozone during the MIS 3 interstadial (VS1 paleosol layer). The warm/mild climatic conditions were only once interrupted by cooler conditions in the MZ-4 paleozone, but the malacological results did not show a strong decrease in temperature. In contrast to paleoclimate results, the changes of local forest cover produced much more diversified results. The highest forest cover was reconstructed for MZ-3 (cool climate) and MZ-4 (mild climate) paleozones, yet the lowest forest coverage could be identified in MZ-2 (warm) paleozone.

The reconstructed paleozones in the Máza sequence display much colder climatic conditions than at Villánykövesd. Considering that the sequences were deposited nearby during mostly the same period, the reconstructed temperature difference is apparent (Fig. 7). Two cold, three mild and four cool paleozones could be separated. The MZ-2 and MZ-4 paleozones are chronologically parallel, with the same paleozones of Villánykövesd. The mild zones all correspond with paleosols (related to MS1, ML1S1 and MS0). From the cold periods, MZ-4 refers to Heinrich event 2, MZ-8 corresponds to the LGM period (Bond et al., 1993; Björck et al., 1998; Hemming, 2004; Gibbard and Cohen, 2008). The highest forest cover corresponds to the cool paleozones, however still subordinate in respect to open vegetation.

The chronological and paleoecological correlation of the Villánykövesd and Máza sequences gave the opportunity to correlate these to other similar aged loess-paleosol sequences, such as sequences from the left bank of Danube River, Katymár (Sümegi, 2007) and Madaras (Hupuczi, 2012) from Hungary and Črvenka 


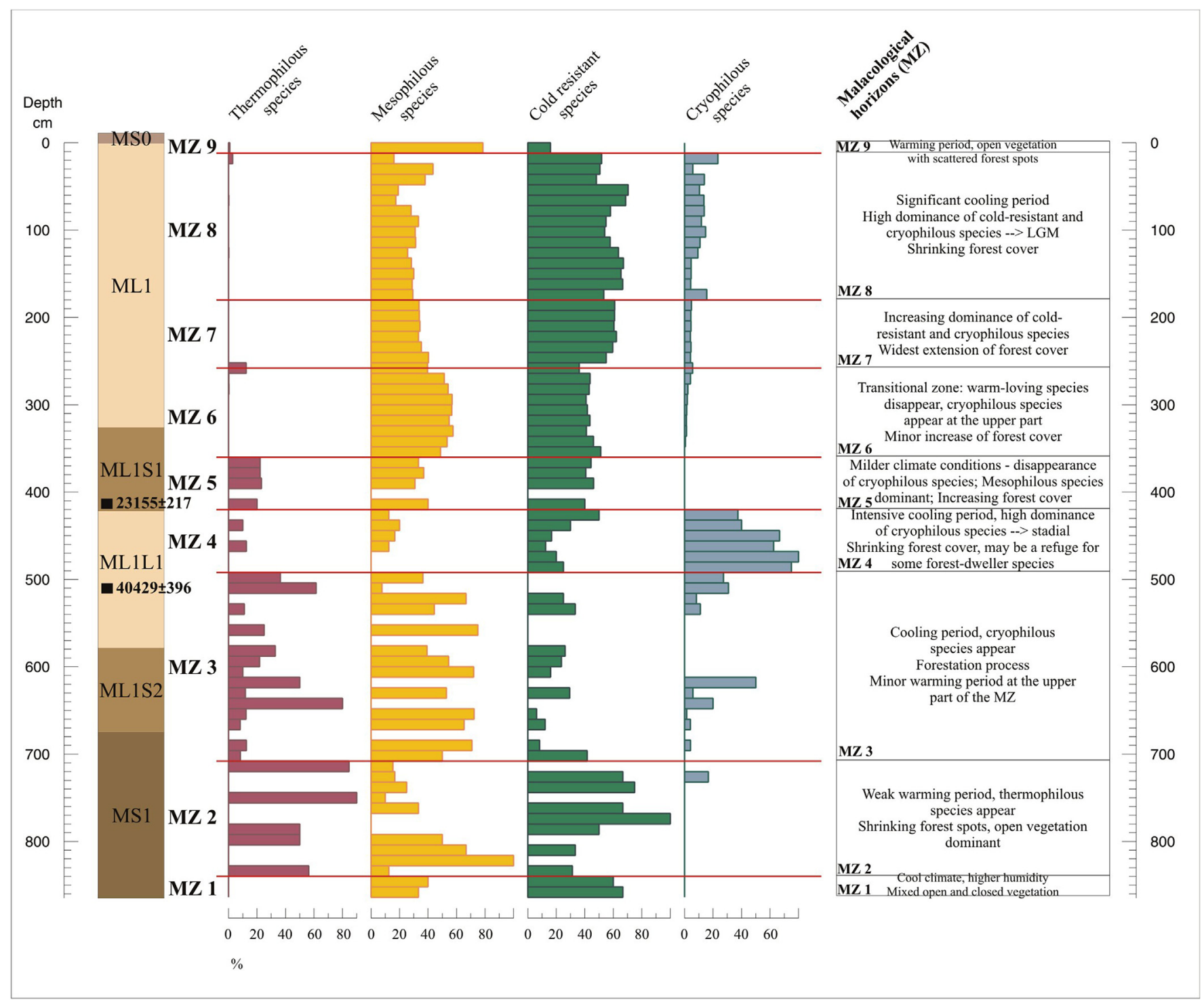

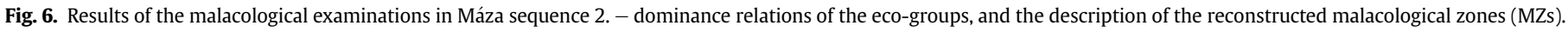

(Sümegi et al., 2016) from Serbia. Interesting similarities are noticed in the snail dominance tendencies among the investigated sequences in three periods (Table 1 ).

In the period younger than 22,000 cal BP years, the clear dominance of Succinella oblonga, Trocholus hispidus, Vallonia tenuilabris, Columella columella and Pupilla muscorum is noticed in the Máza sequence. A similar dominance can be observed in the Madaras sequence (Hupuczi, 2012), only the dominance of P. muscorum is lower. At Katymár, a similar dominance situation is present, although the dominance values of S. oblonga are lower. In the Villánykövesd sequence this dominance connection is missing, because of the continuously warmer climatic conditions. Another dominance connection could be established in the period older than 25,000 cal BP years, where the significant dominance of Pupilla triplicata and Vallonia costata is present in the Villánykövesd, Máza and Črvenka sequences. Only the main dominance of $P$. triplicata could noticed in Katymár sequence. Unfortunately, the oldest parts of Katymár and Madaras sequences are not older than 35,000 cal BP years, thus older similarities can only be investigated for the Villánykövesd, Máza and Črvenka sequences' 35,000 cal BP years older parts. This relation is the Pupilla triplicata, Vallonia costata and Helicopsis striata dominance, which demonstrable in all sequences of Villánykövesd, Máza and Črvenka (Table 1).

\section{Conclusions}

Examining the malacological results of the Villánykövesd and Máza sequences in SW Hungary, several important conclusions can be made. The sedimentary material of the sequences was deposited in a similar period, this means the sequences are of similar age $\left({ }^{14} \mathrm{C}\right.$ dating, Fig. 7). Despite of the chronological correspondence, the paleoecological reconstruction in both sequences produced different results. Global climatic impacts affected the investigated areas, as the cool zones during MIS 2, and milder zones in MIS 3. However, the number and the climatic and environmental conditions of the paleozones of Villánykövesd and Máza show evidence that the previously verified mosaic-like environmental patterns in the Carpathian Basin (Sümegi, 1995, 1996, 2005, 2007; Sümegi and Krolopp, 1995, 2002; Sümegi and Hertelendi, 1998) were present in the area of Villánykövesd and Máza during the Pleistocene as well. This means that a different and unique paleoecological system, the so-called local pattern or scheme (Sümegi, 1996, 2001, 2005), 


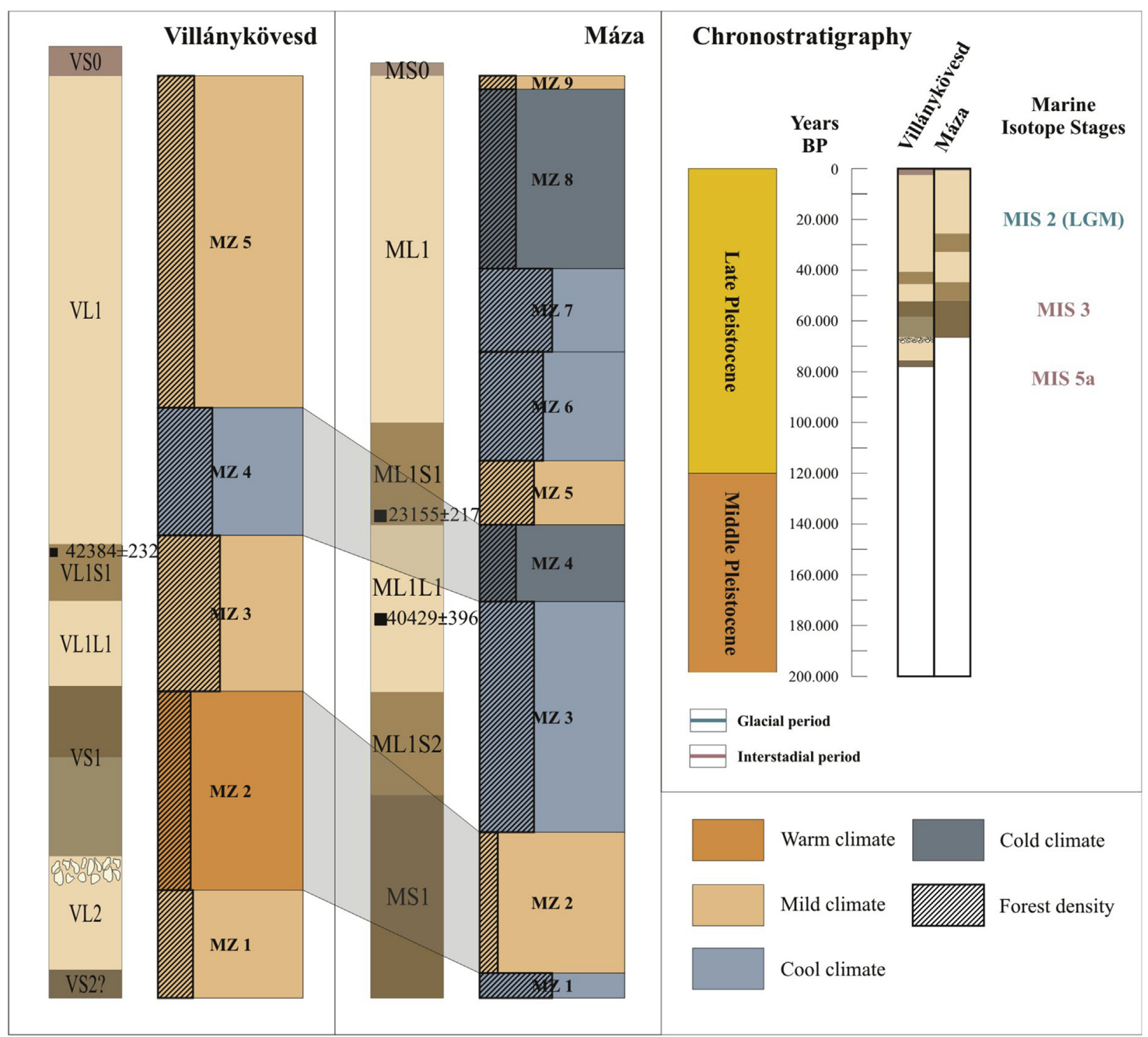

Fig. 7. Results of chronological and paleoecological correlations between Villánykövesd and Máza sequences.

Table 1

Dominance connections between loess-paleosol sequences from the right (Villánykövesd, Máza) and left (Madaras, Katymár, Črvenka) bank of the Danube River.

\begin{tabular}{|c|c|c|c|c|c|}
\hline \multirow[t]{2}{*}{ Age } & \multicolumn{5}{|l|}{ Sequences } \\
\hline & Villánykövesd & Máza & Madaras (Hupuczi, 2012) & Katymár (Sümegi, 2007) & Črvenka (Sümegi et al., 2016) \\
\hline & & S. oblonga & S. oblonga & & \\
\hline & & T. hispidus & T. hispidus & T. hispidus & \\
\hline & & V. tenuilabris & V. tenuilabris & V. tenuilabris & \\
\hline & & C. columella & C. columella & C. columella & \\
\hline 22,000 cal BP yr & & P. muscorum & & & \\
\hline \multirow[t]{2}{*}{25,000 cal BP yr } & P. triplicata & P. triplicata & & P. triplicata & P. triplicata \\
\hline & V. costata & V. costata & & & V. costata \\
\hline \multirow[t]{3}{*}{35,000 cal BP yr } & P. triplicata & P. triplicata & & & P. triplicata \\
\hline & V. costata & V. costata & & & V. costata \\
\hline & H. striata & H. striata & & & H. striata \\
\hline
\end{tabular}

formed in each of these two close-by sequences.

The local climatic impacts are influencing the development of the fauna and the flora. At Máza 9 paleoecological zones could be identified, at Villánykövesd only 5. At Villánykövesd, warmer local climatic conditions resulted in high abundances of thermophilous snails. Only one of them, the Pupilla triplicata, had an outstanding dominance in nearly the all samples of the sequence (Fig. 3). During the cool period (MZ-4) its dominance values did not decrease lower 
than $30-35 \%$, meaning this species was present at the time when the climatic and environmental conditions were unideal for the warmth-loving species (Fig. 3). This means that the area of Villánykövesd was a refuge of $P$. triplicata during the cold period(s) of the Late Pleistocene.

The significant presence of the cold-resistant and the cryophilous species in the Máza sequence indicates generally much lower temperatures than at Villánykövesd. Such cryophilous species appeared in the cold paleozones (Vallonia tenuilabris, Pupilla alpicola), which nowadays occur in high mountainous regions, indicating cold periods in this area during the Late Pleistocene. The geographic situation of the area (on a north-ascending bench; Fig. 2) have influenced the MZs in the sequence, because this area may have functioned as a passage between the higher and lower altitudes, resulting this "passage effect" of the snails.

There are common conformities in the vegetation development. The forest covered areas had the largest extension during cool periods, and covered the smallest areas during cold and warm periods. The high forest density is caused by the increased humidity during cool periods, which enabled the development of closed vegetation areas (forest; Sümegi, 2005; Molnár et al., 2011). However, too warm or cold climate is not favoured by forest development, this is cause for the prevalence of the open vegetation during these periods.

Considering the reconstructed dominance connections with the investigated Sites Madaras, Katymár and Črvenka, it can be said that, aside from the local patterns, during diverse periods similar snail communities developed in each sequence. The bed-migration of the Danube River during the Late Pleistocene did apparently not influence the development of these snail communities.

\section{Acknowledgments}

This work has enjoyed support from the grant GINOP-2.3.2-152016-00009. Authors would like to thank Dr. Christian Zeeden for the pre-review of the manuscript and the language improvements.

\section{References}

An, Z.S., Liu, T.S., Lu, Y.C., Porter, S.C., Kukla, G., Wu, X., Hua, Y.M., 1990. The longterm paleomonsoon variation recorded by the loess-paleosol sequence in Central China. Quat. Int. 7/8, 91-95.

Ant, H., 1963. Faunistiche, ökologische und tiergeographische Untersuchungen zur Verbreitung der Landschenken in Nord-westdeutschland. Abhandlugen aus dem Landesmuseum für Naturkunde zu Münster in Westfalen 25, 1-125.

Bennett, K.D., 1992. PSIMPOLL - a quickBASIC program that generates PostScript page description files of pollen diagrams. In: INQUA Commission for the study of the Holocene: working group on data handling methods, Newsletter, 8, pp. $11-12$.

Björck, S., Walker, M.J.C., Cwynar, L.C., Johnsen, S., Knudsen, K.L., Lowe, J.J., Wohlfarth, B., intimate members, 1998. An event stratigraphy for the Last Termination in the North Atlantic region based on the Greenland ice-core record: a proposal by the INTIMATE group. J. Quat. Sci. 13, 283-292.

Bond, G.C., Broecker, W.S., Johnsen, S., McManus, J.F., Labeyrie, L., Jouzel, J., Bonani, G., 1993. Correlation between climate records from North Atlantic sediments and Greenland ice. Nature 365, 143-147.

Boycott, A.E., 1934. The habitats of land Mollusca in Britain. J. Anim. Ecol. 22, 1-38.

Bösken, J., Sümegi, P., Zeeden, C., Klasen, N., Gulyás, S., Lehmkuhl, F., 2017. Investigating the last glacial Gravettian site 'Ságvár Lyukas Hill' (Hungary) and its paleoenvironmental and geochronological context using a multi-proxy approach. Paleogeogr. Paleoclimatol. Paleoecol. (in press).

Bronger, A., 2003. Correlation of loess-paleosol sequences in east and central asia with SE central europe: towards a continental quaternary pedostratigraphy and paleoclimatic history. Quat. Int. 106-107, 11-31.

Ding, Z.L., Derbyshire, E., Yang, S.L., Sun, J.M., Liu, T.S., 2005. Stepwise expansion of desert environment across northern China in the past 3.5 Ma and implications for monsoon evolution. Earth Planet Sci. Lett. 237, 45-55.

Galović, L., Frechen, M., Halamić, J., Durn, G., Romić, M., 2009. Loess chronostratigraphy in Eastern Croatia - a luminescence dating approach. Quat. Int. 198, 85-97.

Gibbard, P.L., Cohen, K.M., 2008. Global chronostratigraphical correlation table for the last 2.7 million years. Episodes 31, 243-247.

Hemming, S.R., 2004. Heinrich events: massive late Pleistocene detritus layers of the north atlantic and their global climate imprint. Rev. Geophys. 42, 1-43. Horváth, A., 1954. A paksi pleisztocén üledékek csigái és értékelésük. Allattani Kozl. 44, 171-185 (in Hungarian).

Hum, L., 1998. Délkelet-dunántúli Lösz-paleotalaj Sorozatok Keletkezésének Rekonstrukciója Üledéktani, Geokémiai És Oslénytani Vizsgálatok Alapján. PhD thesis. József Attila Tudományegyetem, Szeged, p. 140 (in Hungarian).

Hum, L., Sümegi, P., 2001. Dunaszekcsői pleisztocén rétegsorok malakológiai vizsgálatai. Malakol. Tajekoztato 19, 17-27 (in Hungarian).

Hupuczi, J., 2012. Egy Egyedülálló Dél-alfödi Löszszelvény Malakológiai Vizsgálata És a Terület Felső-würm Paleoklimatológiai Rekonstrukciója. PhD thesis. Szegedi Tudományegyetem, Szeged, p. 113 (in Hungarian).

Hupuczi, J., Sümegi, P., 2010. The Late Pleistocene paleoenvironment and paleoclimate of the Madaras section (South Hungary) based on preliminary records from mollusks. Cent. Eur. J. Geosci. 2, 64-70.

Johnsen, S., Dahl-Jensen, D., Dansgaard, W., Gundestrup, N., 1995. Greenland paleotemperatures derived from GRIP bore hole temperature and ice-core isotope profiles. Tellus 47B, 624-629.

Kerney, M.P., Cameron, R.A.D., Jungbluth, J.H., 1983. Die Landschenken Nord- Ind Mitteleuropas. Verlag Paul Parey, Hamburg-Berlin, p. 384 (in German).

Krolopp, E., 1983. A Magyarországi Pleisztocén Képződmények Malakológiai Tagolása. CSc thesis. Magyar Állami Földtani Intézet, Budapest, p. 160 (in Hungarian).

Krolopp, E., Sümegi, P., 1992. A magyarországi löszök képződésének paleoökológiai rekonstrukciója Mollusca fauna alapján. In: Gy, Szöör (Ed.), Fáciesanalitikai, Paleobiogeokémiai És Paleoökológiai Kutatások. MTA Debreceni Akadémia Bizottság, Debrecen, pp. 247-263 (in Hungarian).

Krolopp, E., Sümegi, P., 1995. Paleoecological reconstruction of the Late Pleistocene based on loess malacofauna on Hungary. Geojournal 36, 213-222.

Lisiecki, L.E., Raymo, M.E., 2005. A plio-pleistocene stack of 57 globally distributed benthic $\delta^{18} \mathrm{O}$ records. Paleoceanography 20. PA1003 1-17.

Ložek, V., 1964. Quartarmollusken der Tschechoslowakei, vol. 31. Rozpravy Ústredniho ústavu geologického, Praha, p. 374 (in German).

Marković, S.B., McCoy, W.D., Oches, E.A., Savić, S., Gaudenyi, T., Jovanović, M. Stevens, T. Walther, R., Ivanišević, P., Galić, Z., 2005. Plaeoclimate record in the upper Pleistocene loess-paleosol sequence at Petrovaradin brickyard (Vojvodina, Serbia). Geol. Carpathica 56/6, 545-552.

Marković, S.B., Oches, E., Gaudenyi, T., Jovanović, M., Hambach, U., Zöller, L. Sümegi, P., 2004. Paleoclimate record in the late Pleistocene loess-paleosol sequence at miseluk (Vojvodina, Serbia). Quaternaire 15, 361-368.

Marković, S.B., Oches, E., McCoy, W., Frechen, J., Gaudenyi, T., 2007. Malacological and sedimentological evidence for "warm" glacial climate from the Irig loess sequence, Vojvodina, Serbia. G-cubed 8, 1-12.

Marković, S.B., Oches, E., Sümegi, P., Jovanović, M., Gaudenyi, T., 2006. An introduction to the Middle and Upper Pleistocene loess-paleosol sequence at Ruma brickyard. Vojvodina, Serbia. Quat. Int. 149, 80-86.

Marković, S.B., Bokhorst, M.P., Vandenberghe, J., McCoy, W.D., Oches, E.A., Hambach, U., Gaudenyi, T., Jovanović, M., Zöller, L., Stevens, T., Machalett, B. 2008. Late Pleistocene loess-paleosol sequences in the Vojvodina region, Serbia. J. Quat. Sci. 23, 73-84.

Marković, S.B., Stevens, T., Kukla, G., Hambach, U., Fitzsimmons, K.E., Gibbard, P., Buggle, B., Zech, M., Guo, Z., Hao, Q., Wu, H., O'Hara-Dhand, K., Smalley, I., Úvári, G., Sümegi, P., Timar-Gabor, A., Veres, D., Sirocko, F., Vasiljević, D., Jary, Z., Svensson, A., Jović, V., Lehmkuhl, F., Kovács, J., Svirčev, Z., 2015. Danube loess stratigraphy - towards a pan-European loess stratigraphic model. Earth Sci. Rev. 148, 228-258.

Molnár, D., Sümegi, P., 2016. Dél-dunántúli és kelet-horvátországi lösz-paleotalaj szelvények paleoökológiai rekonstrukciója malakológiai és üledéktani adatok segítségével. In: Unger, J., Pál-Molnár, E. (Eds.), Geoszférák 2015. GeoLitera, Szeged, pp. 185-209 (in Hungarian).

Molnár, D., Hupuczi, J., Galović, L., Sümegi, P., 2010. Preliminary malacological investigation on the loess profile at Zmajevac, Croatia. Cent. Eur. J. Geosci. 2/1 $52-56$.

Molnár, D., Sávai, Sz, Fekte, I., Sümegi, B.P., Sümegi, P., 2014. A Kárpát-medence dél részén található löszszelvények összehasonlító elemzése - előzetes adatok. In: Sümegi, P. (Ed.), Környezetföltani És Környezettörténeti Kutatások a Dunai Alföldön. GeoLitera Kiadó, Szeged, pp. 121-133 (in Hunagrian).

Molnár, D., Sávai, Sz, Hupuczi, J., Galović, L., Sümegi, P., 2011. Kelet-horvátroszág Lösz-paleotalaj Sorozatok Malakológiai Elemzése, Archeometriai Mủhely, 2011 2. pp. 127-136 (in Hunagrian).

Munsell, A.H., 1905. A Color Notation. G.H. Ellis Company, Boston, p. 89.

Persaits, G., Sümegi, P., 2011. A fitolitok szerepe a régészeti geológiai és környezettörténeti minták értékelésében. In: Unger, J., Pál-Molnár, E. (Eds.) Geoszférák 2010, GeoLitera Kiadó, Szeged, pp. 307-354 (in Hungarian).

Soós, L., 1943. A Kárpát-medence Mollusca-faunája. In: Magyarország Természetrajza I. Állattani Rész. Akadémiai Kiadó, Budapest, p. 478 (in Hungarian).

Stuiver, M., Reimer, P.J., 1993. Extended 14C data base and revised CALIB 3.0 14C Age calibration program. Radiocarbon 35/1, 215-230.

Sümegi, P., 1989. A Hajdúság Felső-pleisztocén Fejlődéstörténete Finomrétegtani (Üledékföldtani, Oslénytani, Geokémiai) Vizsgálatok Alapján. PhD thesis. Kossuth Lajos Tudományegyetem, Debrecen, p. 96 (in Hungarian).

Sümegi, P., 1995. Quartermalacological analysis of late-pleistocene loess sediments of the great Hungarian plain. In: Fúköh, L. (Ed.), Quaternary Malacostratigraphy in Hungary, pp. 79-111. Malacological Newsletter Suppl., 1.

Sümegi, P., 1996. Az ÉK-magyarországi Löszterületek Összehasonlító Oskörnyezet Rekonstrukciója És Rétegtani Értékelése. CSc thesis. Kossuth Lajos 
Tudományegyetem, Debrecen, p. 120 (in Hungarian).

Sümegi, P., 2001. A Negyedidőszak Földtanának És Oskörnyezettanának Alapjai. JATEPress, Szeged, p. 262 (in Hungarian).

Sümegi, P., 2003. A Régészeti Geológia És a Történeti Ökológia Alapjai. JATEPress Szeged, p. 223 (in Hungarian).

Sümegi, P., 2004. Coring and field procedure. In: Sümegi, P., Gulyás, S. (Eds.), The Geohistory of Bátorliget Marshland. Archaeolingua Press, Budapest, p. 50.

Sümegi, P., 2005. Loess and Upper Paleolithic Environment in Hungary. Aurea Kiadó, Nagykovácsi, p. 312.

Sümegi, P., 2007. Magyarország Negyedidőszak Végi Környezettörténete (Az Elmúlt 34 Ezer Év Üledékföldtani És Malakológiai Változásai Magyarországon). DSc thesis. Szegedi Tudományegyetem, MTA Régészeti Intézet, Szeged-Budapest, p. 545 (in Hungarian).

Sümegi, P., Hertelendi, E., 1998. Reconstruction of microenvironmental changes in Kopasz Hill loess area at Tokaj (Hungary) between 15000-70000 BP years. Radiocarbon 40, 855-863.

Sümegi, P., Krolopp, E., 1995. A magyarországi würm korú löszök képződésének paleoökológiai rekonstrukciója Mollusca-fauna alapján. Foldtani Kozlony 125, 125-148 (in Hungarian).

Sümegi, P., Krolopp, E., 2002. Quartermalacological analyses for modelling of the upper weichselian paleoenvironmental changes in the Carpathian Basin. Quat. Int. 91, 53-63.
Sümegi, P., Náfrádi, K., Molnár, D., Sávai, Sz, 2014. Results of paleoecological studies in the loess region of Szeged-Othalom (SE Hungary). Quat. Int. 357, 1-13.

Sümegi, P., Marković, S.B., Molnár, D., Sávai, Sz, Náfrádi, K., Szelepcsényi, Z. Novák, Zs, 2016. Crvenka loess-paleosol sequence revisited: local and regional Quaternary biogeographical inferences of the southern Carpathian Basin. Open Geosci. 8, 390-404.

Sysoev, A.V., Schileyko, A.A., 2009. Land Snails and Slugs of Russia and Adjacent Countries. Pensoft, Sofia\&Moscow, p. 312.

Tzedakis, P.C., Hooghiemstra, H., Pälike, H., 2006. The last 1.35 million years at Tenaghi Philippon: revised chronostratigraphy and long-term vegetation trends. Quat. Sci. Rev. 25, 3416-3430.

Újvári, G., Kovács, J., Varga, Gy, Raucsik, B., Marković, S.B., 2010. Dust flux estimates for the Last Glacial Period in East Central Europe based on terrestrial records of loess deposits: a review. Quat. Sci. Rev. 29, 3157-3166.

Újvári, G., Molnár, M., Novothny, Á., Páll-Gergely, B., Kovács, J., Várhegyi, A., 2014. AMS ${ }^{14} \mathrm{C}$ and OSL/IRSL dating of the Dunaszekcső loess sequence (Hungary): chronology for 20 to $150 \mathrm{ka}$ and implications for establishing reliable age-depth models for the last 40 ka. Quat. Sci. Rev. 106, 140-154.

Újvári, G., Molnár, M., Páll-Gergely, B., 2016. Charcoal and mollusc shell ${ }^{14} \mathrm{C}$-dating of the Dunaszekcsö loess record, Hungary. Quat. Geochronol. 35, 43-53.

Welter-Schultes, F., 2012. European non-marine molluscs, a guide for species identification. Planet Poster Editions, Göttingen, p. 679. 